\title{
Training as a factor of business excellence
}

María Luz Marín-Díaz, Xavier Llinas-Audet, Luis Chiaramonte-Cipolla

Universitat Politècnica de Catalunya (Spain)

luzmaluis@yahoo.com, xavier.llinas@upc.edu, luis.alejandro.chiaramonte@upc.edu

Received December, 2010

Accepted May, 2011

\section{Abstract}

Purpose: Adopting a specific strategy is sometimes the key to the survival of companies. Given the increasing interest on the part of the companies to have the best strategy that allows them to differentiate themselves from their competitors, the aim of this empirical work is to study the relationship that exists between training and business results.

Design/methodology/ approach: The empirical set of this paper is comprised by a survey applied to 381 large organizations in Catalonia region during the time frame of 2006-2007. At one hand, the survey allowed identifying the independent (training) variables, and at other, the dependent variables (economical) were obtained from Sabi Data Base and from the “Fomento de la Producción" Magazine.

Findings: According to data obtained, it is possible to consider training as an additional strategic tool that should be used by companies to improve their performance outcomes.

Originality/value: Taking into account that the literature review only demonstrates studies linking training and results such as total shareholder return, productivity, higher quality of customer services, reduced staff turnover, organizational performance, growth on the staff wages, etc., therefore, the key value of the paper rely at one hand on providing an analysis of the impact of training on billing and at other, on the use of the 
Model of Industrial Economy as part of the theoretical framework for the causal model development.

Keywords: training, performance, productivity, competitiveness, knowledge

Jel Codes: M53

\section{I ntroduction}

In the current business context, one of the most pressing concerns is the pursuit of competitive advantage. The companies that are durable over time will be those that can transform their organisations and adapt themselves to the changeable nature of the business environment, to increasing competition, and to the everevolving needs of clients. In this context, the authors believe that training can be one of the principal variables that contribute to the advantage which separates a business from its competitors. Bearing these issues in mind, success depends on abilities and education, giving rise to the need for the continuous development and updating of skills (Drucker, 1993; Handy, 1997).

Because dealing with this phenomenon of change is critical for the survival of organizations, they have to be prepared to confront it successfully. This means that not only the management and administration of the change must be effective, but also the preparation of, and support for the workforce; in summary, it involves the entire the organization (Mincer, 1958; Schultz, 1961; Denison, 1979; Becker, 1983).

According to Drucker (1999) and Davenport et al. (1998), it is increasingly more evident that knowledge will become the basis of work in the future. Furthermore, the new knowledge society demands that companies have some level of social responsibility for both their staff and the environment; therefore, they must prepare to embrace knowledge (Escardibul et al., 2010; Salazar, 2004)

This investigation aims to contribute to the debate, presenting the concept of training as a key element in the facilitation of change management, dealing with the uncertainty and ambiguity of current times, and to provide the organization with a tool which allows it to increase its capacity to respond and adapt to the challenges of the business environment, recognising the essential role of training as a means of obtaining competitive advantage (Hope et al., 1998). Moreover, the survival of a company depends on its capacity to capture intelligence, to transform 
it into knowledge, to incorporate it as organisational knowledge and to disseminate that knowledge rapidly throughout the entire company (Morrow et al., 1997; Lupton et al., 1999; Collins \& Clark, 2003; Landeta et al., 2009). In fact, there are authors who assert that companies which invest more money in training and development have more success (Barrett \& O'Connell, 2001; Schonewille, 2001; Kraiger, 2003; Birdi et al., 2008). The following section presents an analysis of the work of various authors who have studied the relationship between training and a diverse range of commercial results such as profit, productivity, competitive advantage and other aspects of business revenue (Aragón-Sanchez et al., 2010).

\section{Training and economic performance: Background and hypotheses}

\section{Studies that relate to training and profit}

In studies by Schumpeter (1982), Dickson et al. (1986), Olavarrieta and Friedmann (1999), Cooke (2001), Bassi et al. (2002), Molina and Ortega (2003) and Myers et al. (2004), have examined the strategies that companies have adopted in order to improve labour productivity. The results highlighted the importance of the growth in investment in human capital in order to improve organisational profit, emphasising a positive and significant relationship between investment in training and the total return to shareholders.

\section{Studies that relate training and productivity}

The second group of authors includes Black \& Lynch (1996), Bartel (2000) who cited Bishop (1988), Holzer (1993), Tan and Batra (1995), Huselid (1995), Ichniowski (1997), Krueger and Rouse (1998), Barron et al. (1997), Tennant et al. (2002) and Chu (2005). In their studies, these authors analysed the impact of training on business productivity concluding firstly that the workers who receive additional training go on to increase their salaries, and secondly, that the companies which give their workers more training benefit from a higher return on capital.

\section{Studies that relate training to competitive advantage}

Authors in the third group include writers such as Lynch (1998), Papalexandris and Nikandrou (2000); Johannessen and Olsen (2003) who demonstrated that training produces a significant return on investment, and that a strong relationship exists between the adoption of advanced technology and a highly qualified workforce. Similarly, they concluded that training is vital in order to manage unpredictable 
market changes and to improve customer services. It seems clear that knowledge has become an essential economic resource and perhaps the ability to learn more quickly than the competitors can become one of the truly differentiating sources of competitive advantage (Reyes, 2005).

\section{Studies that relate training to other aspects of business profit}

The studies in this last group of articles, by Ballot and Taimaz (1997), Ottersten and Lindh (1999), Nam-Hong et al. (2004); Battu et al. (2004) examined a wide variety of business results. However, they all found positive results in relation to the importance that training has in respect of themes such as technological change, workers' earnings, labour efficiency etc.

These authors concluded that training allows the resolution of commercial management problems, strengthens competitiveness and improves organizational knowledge. Taking all this into account, they determined that the management of knowledge is a new development that enables companies to position themselves more competitively in the market.

These current developments provide the necessary empirical evidence to support further research. Firstly, given the volume of authors that have investigated the existence of a relation between training and results, the importance of the theme is evident. Secondly, taking into account the proposal by Pineda (2002), PonsPeregort (2000), Eguiguren-Huerta (2002), Aragón-Sánchez (2003), who explained that training should be considered as a structured process that involves both the training assessment and the organization of training. Altogether, this can increase the likelihood of successful implementation of training policies in order to achieve better economic performance. Thirdly, the concrete results - the majority being positive - allow for the establishment of a causal relationship that can be proposed in the working hypotheses that follow:

Hypothesis 1: Both the Evaluation of Training (ET) and the Organisation of Training (OT) are indispensable elements in the training process which seeks to improve economic aspects such as productivity, profitability or turnover.

Hypothesis 2: The Organisation of Training is an aspect of the training process that is affected by the importance the company gives to training.

Hypothesis 3: The Evaluation of Training is an aspect of the training process that is affected by the original motivation for, or source of training in the company. 
Hypothesis 4: The Industrial Economy model can include training as an activity that enables a company to achieve definite results.

In summary, the ultimate aim of this investigation is to develop a causal diagram based on the Industrial Economy model that allows the relationship between training and business results to be established.

\section{Methodology}

In order to validate the working hypotheses, counting with the previous agreement of the respectively authors, we have used the survey designed by Pons-Peregort (2000) and Eguiguren-Huerta (2000) for their doctoral thesis development, which are nevertheless appropriately referenced. At one hand, the survey allowed identifying the independent (training) variables, and at other, the dependent variables (economical) were obtained from Sabi Data Base (Analysis System of Iberian Balances) and from the "Fomento de la Producción" Magazine. The time frame chosen was 2006-2007 because it was the period that had the greatest amount of corresponding data relating to both the economic variables and training. The survey was conducted with a group of 381 companies in the region of Catalonia, counting with a response rate of $28 \%$, which means a number of 106 companies. The survey was sent by normal post and by email. The questionnaire was filled by CEOs and HR directors.

It had a total of 63 questions divided into three parts. The former consists of gathering the organization descriptive information; the second part focuses on issues related to the organizational structure and role of training in the organization. Finally, the third part deals with the management training control.

The questionnaire was subjected to a pre-test. The initial questionnaire was sent to a group of experts, both at industrial and university level, all directly related to training subject areas. This pre-test was used to analyze the errors of the initial questionnaire in order to validate the test, to gather comments and suggestions from the experts and at the same time to identify which questions could provide a certain level of ambiguity due both to its incorrect understanding or by their inadequate order presentation.

As follows, in table 1 , the main points regarding the details upon the research technical information are summarized: 


\begin{tabular}{|c|c|}
\hline Sample & $\begin{array}{l}\text { Public and private Spanish companies and overseas } \\
\text { companies with more than } 250 \text { employees and } \\
\text { a billing turnover exceeding } 24 \text { million Euros. }\end{array}$ \\
\hline Scope & Catalonia \\
\hline Sample Size & 381 companies \\
\hline $\begin{array}{l}\text { Person who the } \\
\text { survey has been } \\
\text { sent }\end{array}$ & CEOs and HR Directors \\
\hline Confidence Level & $99 \%(z=2.58)$ \\
\hline Statistical error & $\begin{array}{l}+/-2.99 \text { (for a confidence level of } 99 \% \text { for the weak case } \\
\qquad p=q=0.5 \text { ) }\end{array}$ \\
\hline $\begin{array}{l}\text { Design and } \\
\text { application }\end{array}$ & $\begin{array}{l}\text { A questionnaire with } 63 \text { questions was used to gather } \\
\text { information. It was sent to all companies that met the } \\
\text { requirements. The companies responsible were contacted } \\
\text { by phone in order to arrange the personal interview or, } \\
\text { alternatively, to set up the possibility of answering the } \\
\text { questionnaire by post or email. In the case that an } \\
\text { interview has been agreed, the interview has been } \\
\text { conducted in the interviewee office where the } \\
\text { questionnaire has been filled in and. In other cases, a } \\
\text { telephone follow-up has been conducted in order to } \\
\text { expand the information given about the study and to give } \\
\text { support on completing the questionnaire. }\end{array}$ \\
\hline
\end{tabular}

Table 1. Technical Information Sheet

The variables selected for analysis were chosen according to the bibliographic criteria summarised in the previous sections, which helped to identify which variables related most strongly to the theme of this study. So, for the variables that measure aspects of training, the focus is on those that reflected or explained the importance that the company gave to training, that showed the level of the training department's organisation; in other words, variables that measured the organisation of the company's training system, either directly or indirectly. It was also important to ensure that theoretical frame of reference guaranteed the coherence of the study, thus avoiding a failure in statistical progress due to the lack of theoretical significance.

The set of variables resulting from the selection process, which represented the essence of the study, was used to develop the causal models, and was subjected to the statistical analysis.

\section{Statistical Analysis}

This analysis was carried out in three stages. Firstly using factor analysis; secondly, a modelling strategy was developed following the theory of the structural equation models; then the third and final stage involved the amalgamation of the models with structural equations (Hair et al., 2000; Luque, 2000; Peña, 2002; Pardo \& Ruiz, 2002). 
Factor analysis allowed for the simplification of the dimensionality, and given the typical characteristics of the method, enabled exploration of the way in which the variables were grouped.

The extraction of factors was done by principal components method, for which we used the Varimax rotation method that yielded the results that justify the application of the method shown in Tables 2, 3 and 4:

\begin{tabular}{|c|c|c|}
\hline \multicolumn{3}{|c|}{ KMO and Bartlett's test - Formation Variables } \\
\hline \multicolumn{2}{|c|}{ Measure of sampling adequacy - Kaiser-Meyer-Olkin. } & .544 \\
\hline \multirow{3}{*}{ Bartlett's Test of sphericity } & Approximate Chi-square & 1628.792 \\
\cline { 2 - 3 } & Df & 561 \\
\cline { 2 - 3 } & Sig. & .000 \\
\hline
\end{tabular}

Table 2. KMO and Bartlett's test - Formation variables

\begin{tabular}{|c|c|c|}
\hline \multicolumn{3}{|c|}{ KMO and Bartlett's test - Year 2006} \\
\hline Measure of sampling adequacy - Kaiser-Meyer-Olkin. & .685 \\
\hline \multirow{3}{*}{ Bartlett's Test of sphericity } & Approximate Chi-square & 1306.591 \\
\cline { 2 - 3 } & Df & 231 \\
\cline { 2 - 3 } & Sig. & .000 \\
\hline
\end{tabular}

Table 3. KMO and Bartlett's test - Year 2006

\begin{tabular}{|c|c|c|}
\hline \multicolumn{3}{|c|}{ KMO and Bartlett's test - Year $\mathbf{2 0 0 7}$} \\
\hline \multicolumn{2}{|c|}{ Measure of sampling adequacy - Kaiser-Meyer-Olkin. } & .675 \\
\hline \multirow{2}{*}{ Bartlett's Test of sphericity } & Approximate Chi-square & 1201.997 \\
\cline { 2 - 3 } & Df & 253 \\
\cline { 2 - 3 } & Sig. & .000 \\
\hline
\end{tabular}

Table 4. KMO and Bartlett's test - Year 2007

In all cases the values meet the advices of Kaiser, Meyer, and Olkin: who argue that if the KMO value is $\geq 0.8$ the idea of conducting a factor analysis is relevant, if $\mathrm{KMO}=0.7$, the idea is acceptable and if $\mathrm{KMO}<0.5$ the idea is unacceptable (Luque, 2000).

The results of the factor analysis concerning both the training variables and the economic variables are summarised in tables 5, 6 and 7 respectively. As can be seen in the tables, the percentage of total variance expected in each case shows that the entire sample can be represented by a reduced number of factors, with very little loss of information. 


\begin{tabular}{|c|c|c|c|c|c|c|}
\hline \multirow{2}{*}{ Component } & \multicolumn{4}{|c|}{$\begin{array}{c}\text { Summation of the solutions } \\
\text { from the extraction matrix }\end{array}$} & \multicolumn{2}{c|}{$\begin{array}{c}\text { Summation of the solutions } \\
\text { from the rotated factor matrix }\end{array}$} \\
\cline { 2 - 7 } & Total & $\begin{array}{c}\% \text { of } \\
\text { variance }\end{array}$ & $\begin{array}{c}\% \\
\text { cumulative }\end{array}$ & $\begin{array}{c}\text { Total } \\
\% \text { of } \\
\text { variance }\end{array}$ & $\begin{array}{c}\% \\
\text { cumulative }\end{array}$ \\
\hline $\mathbf{1}$ & 8.644 & 13.720 & 13.720 & 6.871 & 10.906 & 10.906 \\
\hline $\mathbf{2}$ & 6.569 & 10.428 & 24.148 & 6.230 & 9.889 & 20.795 \\
\hline $\mathbf{3}$ & 6.073 & 9.640 & 33.788 & 5.851 & 9.288 & 30.083 \\
\hline $\mathbf{4}$ & 5.572 & 8.845 & 42.633 & 5.534 & 8.784 & 38.867 \\
\hline $\mathbf{5}$ & 4.415 & 7.008 & 49.641 & 5.184 & 8.229 & 47.096 \\
\hline $\mathbf{6}$ & 4.043 & 6.417 & 56.058 & 4.731 & 7.510 & 54.606 \\
\hline $\mathbf{7}$ & 3.677 & 5.837 & 61.895 & 4.592 & 7.288 & 61.895 \\
\hline
\end{tabular}

Table 5. Results obtained through the extraction method: Analysis of Principal Components

\begin{tabular}{|c|c|c|c|c|c|c|}
\hline \multirow[t]{2}{*}{ Component } & \multicolumn{3}{|c|}{$\begin{array}{l}\text { Summation of the solutions } \\
\text { from the extraction matrix }\end{array}$} & \multicolumn{3}{|c|}{$\begin{array}{l}\text { Summation of the solutions } \\
\text { from the rotated factor matrix }\end{array}$} \\
\hline & Total & $\begin{array}{c}\% \text { of } \\
\text { variance }\end{array}$ & $\begin{array}{c}\% \\
\text { cumulative }\end{array}$ & Total & $\begin{array}{c}\% \text { of } \\
\text { variance }\end{array}$ & $\begin{array}{c}\% \\
\text { cumulative }\end{array}$ \\
\hline 1 & 12.518 & 36.819 & 36.819 & 8.545 & 25.132 & 25.132 \\
\hline 2 & 8.038 & 23.640 & 60.459 & 7.120 & 20.941 & 46.073 \\
\hline 3 & 4.646 & 13.664 & 74.123 & 5.356 & 15.754 & 61.827 \\
\hline 4 & 2.347 & 6.904 & 81.027 & 4.872 & 14.330 & 76.157 \\
\hline 5 & 1.363 & 4.008 & 85.034 & 2.106 & 6.194 & 82.352 \\
\hline 6 & 1.033 & 3.038 & 88.072 & 1.945 & 5.720 & 88.072 \\
\hline
\end{tabular}

Table 6. Results obtained through the extraction method: Analysis of Principal Components

\begin{tabular}{|c|c|c|c|c|c|c|}
\hline \multirow{2}{*}{ Component } & \multicolumn{4}{|c|}{$\begin{array}{c}\text { Summation of the solutions } \\
\text { from the extraction matrix }\end{array}$} & \multicolumn{2}{c|}{$\begin{array}{c}\text { Summation of the solutions from } \\
\text { the rotated factor matrix }\end{array}$} \\
\cline { 2 - 7 } & Total & $\begin{array}{c}\% \text { of } \\
\text { variance }\end{array}$ & $\begin{array}{c}\% \\
\text { cumulative }\end{array}$ & Total & $\begin{array}{c}\% \\
\text { variance }\end{array}$ & cumulative \\
\hline $\mathbf{1}$ & 13.087 & 38.490 & 38.490 & 6.861 & 20.178 & 20.178 \\
\hline $\mathbf{2}$ & 6.288 & 18.495 & 56.986 & 5.524 & 16.247 & 36.426 \\
\hline $\mathbf{3}$ & 4.940 & 14.529 & 71.515 & 5.393 & 15.863 & 52.288 \\
\hline $\mathbf{4}$ & 2.073 & 6.096 & 77.611 & 4.687 & 13.785 & 66.073 \\
\hline $\mathbf{5}$ & 1.761 & 5.178 & 82.789 & 4.299 & 12.645 & 78.718 \\
\hline $\mathbf{6}$ & 1.307 & 3.844 & 86.633 & 2.691 & 7.915 & 86.633 \\
\hline
\end{tabular}

Table 7. Results obtained through the extraction method: Analysis of Principal Components

Besides obtaining satisfactory statistical results, the variables were grouped in accordance with the theory and the critical bibliographic review, and this facilitated the assignation of a name for each factor (Chin, 2004; Luque, 2000). The resulting classifications of the factors are presented in tables 8 and 9.

\begin{tabular}{|c|c|c|}
\hline \multicolumn{3}{|c|}{ TRAI NI NG VARI ABLES } \\
\hline Extracted Factor & Name assigned to the factor & Abbreviation \\
\hline Factor 1 & Evaluation of Training & ET \\
\hline Factor 2 & Importance of Training & IT \\
\hline Factor 3 & Training Base & TB \\
\hline Factor 4 & Source of Training & ST \\
\hline Factor 5 & Organisation of Training & OT \\
\hline Factor 6 & Priority of Training & PT \\
\hline Factor 7 & Revision and Costs of Training & RCT \\
\hline
\end{tabular}

Table 8. Training variables 


\begin{tabular}{|c|c|c|}
\hline & ECONOMI C VARI ABLES 2006 \\
\hline Extracted Factor & Name assigned to the factor & Abbreviation \\
\hline Factor 1 & General Expenditure and Costs & GEC \\
\hline Factor 2 & Profitability & P \\
\hline Factor 3 & Productivity and Unitary Labour Costs & PULC \\
\hline Factor 4 & Size and Costs & SC \\
\hline Factor 5 & Turnings & T \\
\hline Factor 6 & ECONOMI C VARI A BLE 2007 & Abbreviation \\
\hline Extracted Factor & Name assigned to the factor & GEC \\
\hline Factor 1 & General Expenditure and Costs & PULC \\
\hline Factor 2 & Productivity and Unitary Labour Costs & FP \\
\hline Factor 3 & Financial Profitability & T \\
\hline Factor 4 & Turnover & SC \\
\hline Factor 5 & Size and Costs & EP \\
\hline Factor 6 & Economic Profitability & \\
\hline
\end{tabular}

Table 9. Economic variables 2006 and 2007

\section{Modelling Strategy}

Given that the level of modification to a model does not guarantee that the best option has been found, the method known as Strategy of Model Development was applied, providing the opportunity to work with the best possible option of model (Hair et al., 2000).

The model was conceived by strictly following the rules established for modelling with structural equations. That is to say, it is a model through which dependent relationships between the variables considered important in the exploration of the phenomenon studied were established. Therefore the model was based on the theoretical contributions made by the contemporary authors that were reviewed and the Industrial Economy model (Cabral, 1997).

The Industrial Economy model is a general empirical model that includes, in theory, all the relevant variables that influence business results. This was not done in a random way, but rather by structuring the set of the variables in four levels that also influence each one of the following, as shown in figure 1.

Obviously, training in human resources, and all the representative aspects of this business practice, forms part of the BUSINESS ACTIVITIY. Staff training should therefore be expected to feature in theoretical and empirical developments of the Industrial Economy model.

The model presented in this article clearly illustrates that if a company has a training structure (Organisation of Training), and applies training policies (Training and Evaluation of Training), it will consequently obtain strong results (higher turnover, higher earnings and better productivity). 


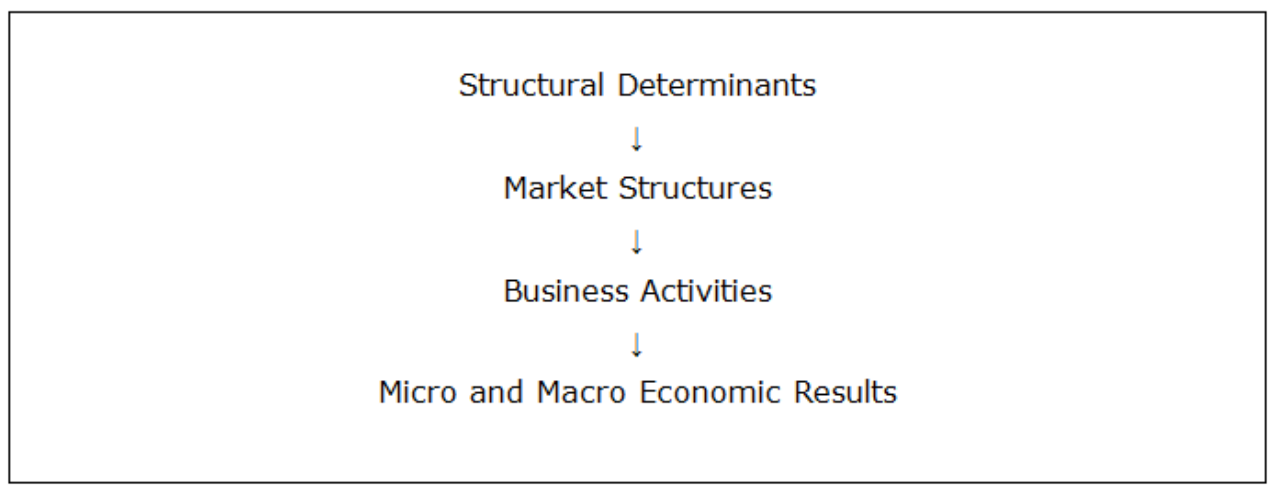

Figure 1. Drawing on Luis Cabral

Figure 2 illustrates the initial causal diagram, which was used as the starting point for its subsequent modification. Its design was based on the structure of the model previously cited.

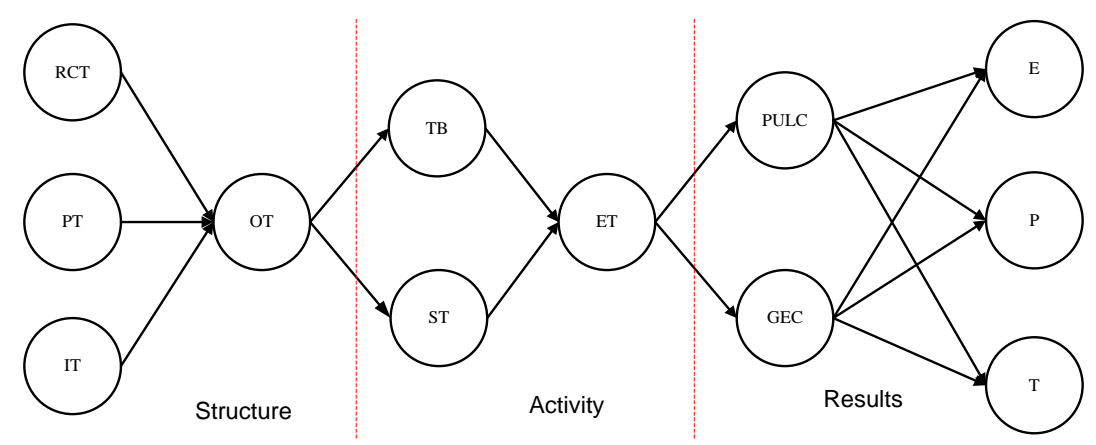

Figure 2. Diagram corresponding to the initial causal model depicting training and results

This model presents a proposal with a very close level of correspondence between the theoretical concepts on which it is based (as were described above). The values expressed in this model can be seen in Table 10 which shows the estimated parameters corresponding to the constructs of the model with an appropriate $\mathrm{R}^{2}$, such as "OT" and "ET", whilst also identifying constructs which did not satisfy the condition, for example "TB" and "ST".

\begin{tabular}{|c|c|c|}
\hline Construct & R2 Year 2006 & R2 Year 2007 \\
\hline Organisation of Training (OT) & 0.7499 & 0.7523 \\
\hline Training Base (TB) & 0.0800 & 0.0810 \\
\hline Source of Training (ST) & 0.2668 & 0.2683 \\
\hline Evaluation of Training (ET) & 0.5760 & 0.6547 \\
\hline Productivity (P) & 0.1565 & 0.0574 \\
\hline General Expenditure and Costs (GEC) & 0.0210 & 0.0206 \\
\hline Benefits & 0.6035 & 0.7838 \\
\hline Profitability (PR) & 0.3329 & 0.2215 \\
\hline Turnover (T) & 0.7466 & 0.7784 \\
\hline
\end{tabular}

Table 10. Results of evaluation of the initial model 
Following the guidelines marked out by the chosen strategy, the model was reorganised until the best was reconciled. That organisation was carried out taking into account the underlying theory which had supported the model, which enabled the maintenance of the necessary conditions for modelling with the structural equation system. In order to remodeling, we have also taken into account the values of both indicators discussed in PLS for the evaluation of the measurement model (reliability of individual items and constructs, etc..) and those used to assess the structural model such as the R2 and Q2 which measures the model adjustment.

This reorganisation of the model gave place to the final model, which illustrated the structure formed by the exogenous constructs called Adjustments and Costs of Training, Priority of Training, Importance of Training and the endogenous construct called Organisation of Training. The second part of the model features constructs that correspond to activities known as Organisation of Training and Evaluation of Training. In the third and final section is the construct of Turnover, which represents the Results. The resulting model is presented in figure 3.

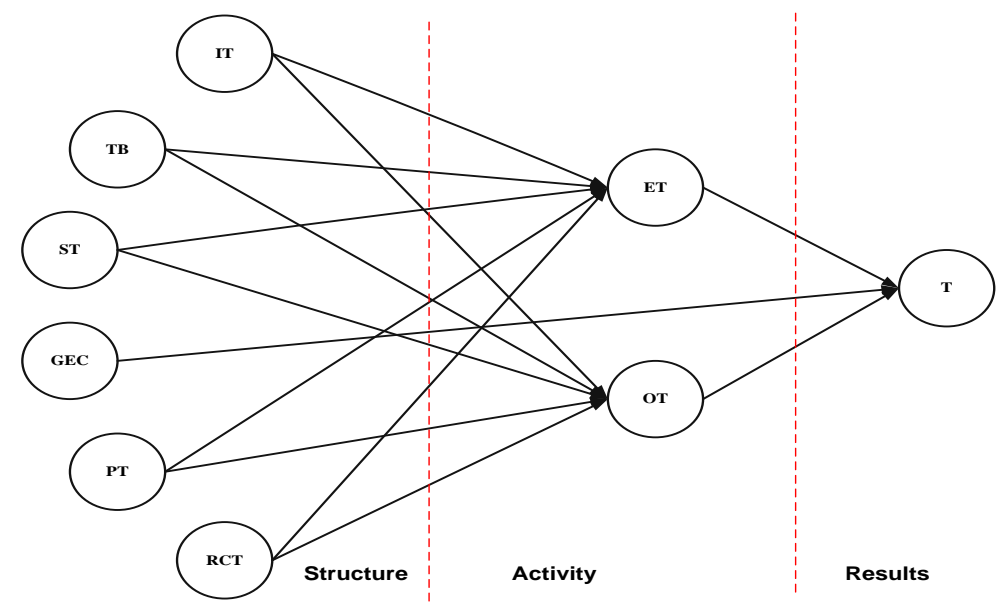

Figure 3. Causal model, depicting the second redefinition of the structural model

The sequence followed in the structural equation analysis addresses the two steps proposed in the literature (Díez Medrano, 1992): the measurement model and the structural model. The measurement model is related to whether the theoretical concepts are properly measured by observed variables. This analysis is done based on validity attributes (it actually measures what you want to measure) and reliability attributes being done in a stable and consistent way. The structural model assesses the weight and magnitude of the relationships between different variables. 


\section{Assessment of the measurement model}

$\underline{\text { Individual item reliability }}$

In a PLS model, individual item reliability is assessed by examining the loads $(\lambda)$, or simple correlations of the measures or indicators with their respective construct. In this manner, the most widely accepted empirical rule is proposed by Carmines and Zeller (1979), who pointed out that in order to accept an indicator as part of a construct, it has to hold a load equal to or greater than 0.707. Tables 11 and 12 show the results of the reliability of items regarding both 2006 and 2007.

\begin{tabular}{|c|c|c|c|c|c|c|c|c|c|c|c|}
\hline $\mathbf{T}$ & & GEC & & ET & & ET & & OT & & OT & \\
\hline Í tem & PLS & ítem & PLS & í tem & PLS & í tem & PLS & Í tem & PLS & ítem & PLS \\
\hline t1 & 0.8421 & gel & 0.8471 & IT & 0.7238 & ST & 0.6790 & IT & 0.8512 & ST & 0.8802 \\
\hline t2 & 0.7811 & ge2 & 0.8024 & it1 & 0.6966 & st1 & 0.7685 & it1 & 0.8322 & st1 & 0.7162 \\
\hline \multirow[t]{11}{*}{ t3 } & 0.7506 & ge3 & 0.6900 & it2 & 0.7170 & st2 & 0.8561 & it2 & 0.7136 & st2 & 0.8353 \\
\hline & & ge4 & 0.7950 & it3 & 0.7742 & st3 & 0.8326 & it3 & 0.7170 & st3 & 0.8768 \\
\hline & & ge5 & 0.7920 & it4 & 0.8770 & st4 & 0.7830 & it4 & 0.8016 & st4 & 0.7582 \\
\hline & & ge6 & 0.8502 & it5 & 0.8756 & st5 & 0.8852 & it5 & 0.8288 & st5 & 0.8161 \\
\hline & & ge7 & 0.8237 & it6 & 0.7555 & st6 & 0.7566 & it6 & 0.7749 & st6 & 0.7670 \\
\hline & & ge8 & 0.7733 & TB & 0.7691 & st7 & 0.7983 & TB & 0.7496 & st7 & 0.7385 \\
\hline & & ge9 & 0.7075 & tb1 & 0.8346 & st8 & 0.8257 & tb1 & 0.7611 & st8 & 0.7739 \\
\hline & & gel0 & 0.7330 & tb2 & 0.7865 & PT & 0.8351 & tb2 & 0.7944 & PT & 0.7593 \\
\hline & & gel0 & 0.8188 & & & pt1 & 0.7229 & & & pt1 & 0,7889 \\
\hline & & ge12 & 0.7879 & & & pt2 & 0.8478 & & & pt2 & 0.8695 \\
\hline & & & & & & & & & & & \\
\hline
\end{tabular}

Table 11. Individual item reliability 2006

\begin{tabular}{|c|c|c|c|c|c|c|c|c|c|c|c|}
\hline $\mathbf{T}$ & & GEC & & ET & & ET & & OT & & OT & \\
\hline ítem & PLS & ítem & PLS & ítem & PLS & ítem & PLS & ítem & PLS & ítem & PLS \\
\hline $\mathrm{t} 1$ & 0.7412 & gel & 0.8321 & IT & 0.8241 & ST & 0.7808 & IT & 0.7873 & ST & 0.8235 \\
\hline t2 & 0.6835 & ge2 & 0.7938 & it1 & 0.7976 & st1 & 0.6629 & it1 & 0.8129 & st1 & 0.6271 \\
\hline \multirow[t]{11}{*}{ t3 } & 0.8560 & ge3 & 0.7223 & it2 & 0.6977 & st2 & 0.7415 & it2 & 0.7937 & st2 & 0.8254 \\
\hline & & ge4 & 0.7348 & it3 & 0.8125 & st3 & 0.7922 & it3 & 0.7260 & st3 & 0.8385 \\
\hline & & ge5 & 0.7835 & it4 & 0.8077 & st4 & 0.8209 & it4 & 0.8161 & st4 & 0.7386 \\
\hline & & ge6 & 0.8208 & it5 & 0.6731 & st5 & 0.6882 & it5 & 0.7878 & st5 & 0.7869 \\
\hline & & ge7 & 0.7973 & it6 & 0.7402 & st6 & 0.8256 & it6 & 0.7594 & st6 & 0.7580 \\
\hline & & ge8 & 0.7554 & TB & 0.8018 & st7 & 0.7983 & TB & 0.7162 & st7 & 0.7737 \\
\hline & & ge9 & 0.6758 & tb1 & 0.7357 & st8 & 0.8164 & tb1 & 0.7416 & st8 & 0.7998 \\
\hline & & ge10 & 0.6389 & tb2 & 0.6841 & PT & 0.7235 & tb2 & 0.8046 & PT & 0.7593 \\
\hline & & ge10 & 0.7781 & & & pt1 & 0.6279 & & & pt1 & 0,7677 \\
\hline & & ge12 & 0.7765 & & & pt2 & 0.7944 & & & pt2 & 0.8294 \\
\hline & & & & & & & & & & & \\
\hline
\end{tabular}

Table 12 . Individual item reliability 2007

\section{Construct reliability}

To compare construct reliability measures we rely on the composite reliability coefficient $(\rho c)$ (Werts et al., 1974). While reliability can also be measured using Cronbach's alpha, we have decided to use the composite reliability proposed by Barclay et al. (1995) and Fornell and Larcker (1981), since the latter has a number of advantages, such as not being influenced by the number of existing items on the scales and the use of loads of items as they exist in the causal model. In both 
techniques the values of composite reliability are acceptable since they are above or very close to 0.7 . Table 13 contains the results of constructs reliability.

With respect to the amount of variance that is used to interpret the indicators of each construct, we have used for comparison purposes, the measure that AVE has provided us. The objective here is that the explained variance would be more than $50 \%$ due to the indicators and due to measurement error.

A construct will be consisted of discriminated validity if the average variance extracted of a construct is greater than the squared correlations between this construct and others that form the model (Fornell \& Larcker, 1981), which indicates that a construct is different from others. The discriminated validity of a construct is calculated by the square root of the $A V E$, which has to be greater than the correlations that occur with other constructs. These values are respectively shown in tables 14 and 15, where the elements of the diagonal correspond to the square root of average variance extracted construct.

\begin{tabular}{|c|c|c|c|c|}
\hline Construct & $\begin{array}{c}\text { Composite reliability } \\
(\mathbf{P C}) \mathbf{2 0 0 6}\end{array}$ & AVE 2006 & $\begin{array}{c}\text { Composite reliability } \\
(\mathbf{p}) \mathbf{2 0 0 7}\end{array}$ & AVE 2007 \\
\hline IT & 0.8960 & 0.6857 & 0.7952 & 0.5685 \\
\hline TB & 0.9207 & 0.6290 & 0.7568 & 0.5902 \\
\hline ST & 0.8488 & 0.5709 & 0.8167 & 0.6629 \\
\hline GEC & 0.8579 & 0.5836 & 0.7739 & 0.6946 \\
\hline PT & 0.9371 & 0.7009 & 0.8202 & 0.6823 \\
\hline RCT & 0.8794 & 0.6123 & 0.8813 & 0.7112 \\
\hline ET & 0.8925 & 0.6845 & 0.7854 & 0.5850 \\
\hline OT & 0.8890 & 0.6082 & 0.8670 & 0.6175 \\
\hline T & 0.9133 & 0.6110 & 0.8419 & 0.6249 \\
\hline
\end{tabular}

Table 13. Construct reliability and statistical analysis of variance

\begin{tabular}{|c|c|c|c|c|c|c|c|c|c|}
\hline & IT & TB & ST & GEC & PT & RCT & ET & OT & T \\
\hline IT & 0.8280 & & & & & & & & \\
\hline TB & 0.7166 & 0.7931 & & & & & & & \\
\hline ST & 0.6852 & 0.6523 & 0.7556 & & & & & & \\
\hline GEC & 0.5490 & 0.6180 & 0.7499 & 0.7639 & & & & & \\
\hline PT & 0.6460 & 0.5932 & 0.6580 & 0.6683 & 0.8371 & & & & \\
\hline RCT & 0.6221 & 0.5738 & 0.7025 & 0.6958 & 0.8044 & 0.7825 & & & \\
\hline ET & 0.5267 & 0.6933 & 0.6763 & & 0.6742 & 0.5741 & 0.8273 & & \\
\hline OT & 0.5628 & 0.7125 & 0.5915 & & 0.6035 & 0.6318 & & 0.7798 & \\
\hline T & & & & 0.7219 & & & 0.7998 & 0.7122 & 0.7816 \\
\hline
\end{tabular}

Table 14. PLC Correlation matrix in 2006

All the constructs meet the condition set by Fornell and Larcker (1981) for PLS, so we can claim to have addressed discriminate validity. 


\begin{tabular}{|c|c|c|c|c|c|c|c|c|c|}
\hline & IT & TB & ST & GEC & PT & RCT & ET & OT & T \\
\hline IT & 0.7539 & & & & & & & & \\
\hline TB & 0.5638 & 0.7682 & & & & & & & \\
\hline ST & 0.7089 & 0.7234 & 0.8141 & & & & & & \\
\hline GEC & 0.6959 & 0.6876 & 0.7818 & 0.8334 & & & & & \\
\hline PT & 0.7265 & 0.6977 & 0.7436 & 0.7873 & 0.8260 & & & & \\
\hline RCT & 0.7369 & 0.6184 & 0.6996 & 0.6789 & 0.8124 & 0.8433 & & & \\
\hline ET & 0.6902 & 0.6392 & 0.7997 & & 0.7590 & 0.6981 & 0.7648 & & \\
\hline OT & 0.7481 & 0.5995 & 0.6621 & & 0.7667 & 0.7257 & & 0.7858 & \\
\hline T & & & & 0.7443 & & & 0.7188 & 0.7293 & 0.7905 \\
\hline
\end{tabular}

Table 15. PLC Correlation matrix in 2007

\section{Assessment of the structural model}

To carry out an appropriate interpretation of the structural model in PLS modeling field, two basic indexes are to be taken into account: the $\mathrm{R}^{2}$ and the standardized path coefficients, which is what PLS attempts to maximize in its algorithm.

In table 16 the statistical results of the structural model are presented. It illustrates the values of $R^{2}$ for the endogenous constructs that form part of the model.

\begin{tabular}{|c|c|c|c|}
\hline \multicolumn{2}{|c|}{ YEAR 2006 } & \multicolumn{2}{c|}{ YEAR 2007 } \\
\hline CONSTRUCT & $\mathbf{R}^{2}$ & CONSTRUCT & $\mathbf{R}^{2}$ \\
\hline Organisation of training & 0.5842 & Organisation of training & 0.8146 \\
\hline Evaluation of training & 0.7038 & Evaluation of training & 0.8485 \\
\hline Turnover & 0.5905 & Turnover & 0.9414 \\
\hline
\end{tabular}

Table 16. Stadistical results of the structural model

Statistically, the coefficient $\mathrm{R}^{2}$ is an intuitive understanding, since it represents a level of income which is obtained by predicting a variable from the information gleaned from other variables, that is to say it is the variability of $Y$ explained by $X$.

The values of $\mathrm{R}^{2}$ must be higher than 0.5 in order for the results to be satisfactory (Chin, 2004; Luque, 2000). In this instance, as is demonstrated in Table 16, the values of $\mathrm{R}^{2}$ are higher than the conventional value for each case.

It is also necessary to analyze the $\mathrm{Q}^{2}$ index developed by Stone (1974) and Geisser (1975), which is usually used in order to measure the predictive relevance or predictability of the dependent constructs. Thus, " $\mathrm{Q}^{2}$ offers a measure of the goodness with which the observed values are reconstructed by the model and its parameters" (Chin, 1998b). If $\mathrm{Q}^{2}>0$, the model has predictive relevance, whereas if $\mathrm{Q}^{2} \leq 0$, the model does not have it.

Since the $\mathrm{Q}^{2}$ obtained value for each year that comprise our case study is 0.6391 and 0.5931 and taking into account the above, we can suggest that the predictability of the model is relevant. 
Seeing the results expounded above, it can be argued that the model analysed with the Structural Equation Model (SEM) by means of the Partial Least Square (PLS) integrated with the Portable Data Analysis System (SPAD) produces positive results. From a strictly empirical point of view, the exogenous constructs foretell the endogenous constructs, which implies that the structure of training established by a company influences its turnover.

On the other hand, having taken the theoretical aspects into account, it can be confirmed that the companies which maintain an organisational structure with regard to training can define objectives, evaluate them, and measure the impact training has on the company's turnover.

\section{Results}

As follows, we described the analysis of the $\beta$ coefficients for both equations of the structural model and the moderation model.

\section{Structural Model}

Equations 1 and 2 correspond to the resulting structural model. As can be seen, the constructs General Expenditure and Costs (GEC), Evaluation of Training (ET) and Organisation of Training (OT) form part of a linear combination that has turnover as an independent variable with regard to the years 2006 and 2007. The mathematical equations that correspond to the model are demonstrated below:

$$
\begin{aligned}
& F_{-} 06=0.7639 \mathrm{GEC}+0.1116 \mathrm{OT}+0.0372 \mathrm{ET} \\
& \mathrm{F} \_07_{-}=0.9615 \mathrm{GEC}+0.0570 \mathrm{OT}+0.0125 \mathrm{ET}
\end{aligned}
$$

The equations make it clear that taking the resultant coefficients into account, General Expenditure and Costs (GEC) is the construct that contributes most to the explanation of turnover. In addition to the values being statistically acceptable, they maintain a close relationship with the coexistence of a cost centre that keeps specific account of the costs of training (Eguiguren-Huerta et al., 2008).

Following the analysis and bearing the resultant coefficients in mind, it was found that the construct Organisation of Training (OT) is the second most important construct in the explanation of turnover, particularly in the case of equation 1.

This is supported by the theory developed by Pineda (2002), which asserts that companies with well-organised training have greater possibilities of obtaining better 
results; it can be seen that the statistical results are completely coherent with the theory studied.

The authors Kirkpatrick (2003); Alliger et al. (1997); Aragón-Sánchez et al. (2003) supply the necessary principles for the justification of the resultant factor, the construct Evaluation of Training (ET). They consider that it does not have a conclusive influence on turnover, but that evaluation is more associated with a modification process of the company's training method; that is to say, evaluation is conducted in order to obtain the student's feedback, to assess the learning and the level of transference and to gauge the economic impact.

\section{Moderation Model}

In order to analyse the moderation model, the following exogenous constructs must be reviewed: the Importance of Training (IT), Training Base (TB), Source of Training (ST), Priority of Training (PT) and Revision and Costs of Training (RCT) giving rise to the following equations:

$$
\begin{aligned}
& \mathrm{ET}=-0.1426 \mathrm{IT}+0.0675 \mathrm{~TB}+0.6533 \mathrm{ST}+0.1831 \mathrm{PT}+0.1440 \mathrm{RCT} \\
& \mathrm{ET}=-0.0409 \mathrm{IT}+0.0845 \mathrm{~TB}+0.8976 \mathrm{ST}+0.0717 \mathrm{PT}+0.0419 \mathrm{RCT} \\
& \mathrm{OT}=0.6887 \mathrm{IT}+0.0103 \mathrm{~TB}+0.3652 \mathrm{ST}-0.0124 \mathrm{PT}+0.0604 \mathrm{RCT} \\
& \mathrm{OT}=0.6441 \mathrm{IT}-0.0660 \mathrm{~TB}+0.5134 \mathrm{ST}-0.0198 \mathrm{PT}-0.0032 \mathrm{RCT}
\end{aligned}
$$

In the same way as for the structural model, the moderation model was analysed to ascertain how much weight each construct has in order to understand the extent to which they explain the endogenous constructs: Organisation of Training (OT) and Evaluation of Training (ET).

The most notable factor to be emphasised, taking the resulting coefficients into account, is the construct of Source of Training, which best explains the constructs of Organisation of Training (OT) and Evaluation of Training (ET). Another factor with a coefficient giving it considerable significance, is the Importance of Training (IT) in respect to the Organisation of Training; the other constructs have a less discreet presence.

As through the entirety of this investigation, theory also endorses these results. For instance, Pineda (2002), suggested that if training is based on solid foundations, meaning a robust process of training needs analysis, then the Evaluation of Training 
and the Organisation of Training will have higher probability of being effective activities and therefore to contributing to the growth of turnover.

\section{Discussions}

Although the reviewed authors throughout the research design and development have provided valuable information regarding the variables of training as well have served as a starting point for our study and theoretical basis for designing our causal model, nonetheless we must highlight that their attempt to measure the relationship between training variables are not strong enough due to the small number of variables they have used.

As such, we have found authors who address formal training (e.g. Tan \& Batra, 1995; Bartel, 2000; Bassi, 2002; Bishop, 1988). For instance, Holzer (1993) used the annual hours of training per employee in his study. Black and Lynch (1996) and Barron et al. (1997) have taken into account the number of trained workers, formal, informal and extra-job training. However, the following authors have used more uncommon training variables, in the case of Krueger and Rose (1998); they have employed the literacy and math levels, while Cook (2001) used the technology training. Finally, Battu et al. (2004) have used variables such as years of education per employee and percentage of trained workers.

However, we believe that in order for training truly achieve its strategic role, a set of variables must be taking into account, that is to say that aspects of training which are essential for the successful implementation of the training process should be acknowledged. In this regard, we find authors such as Pons-Peregort (2000), Eguiguren-Huerta (2000) and Pineda (2002) who considered that training should be well organized, financially controlled and properly evaluated. These concepts comprised what we have called the training process, which should begin with the identification of training needs, go through the organization and implementation of training and finally guarantee the evaluation stage.

Unlike the authors mentioned, we suggest that the causality between training and results will depend on the degree of organization of the training process and will turn out the opposite if we rely only upon isolated variables or aspects of training.

\section{Limitations and future research}

The limitations of this study focus on the study area. The questionnaire was sent to companies located in the Catalonia region, which makes it difficult to generalize the 
results to other regions or countries, as well its comparison to national or international levels.

However, the limitations of this research open new lines of enquiries, allowing us to use a larger sample from different geographical areas in order to generalize the results.

Given the results obtained in this study and taking into account that the increasingly corporate profits affect economic growth in a country or region, due to its transitory character, we could propose a model in order to explore the relationship of training with the local and regional economic growth.

\section{Conclusions}

In the actual business environment one of the most important concern focuses on building competitive advantages. On the other hand, authors such as Mincer (1958), Schultz (1961), Becker (1983) and Denison (1979) argue that training is a key role in any development process, emphasizing that there is a close connection between training and economic variables such as income, employment and business growth.

If companies truly consider people as valuable strategic assets, the CEOs would acquaint that a competent workforce, achieved through the training policies, would be a basic requirement for business success (Stephen, 1997).

We have seen that knowledge is an essential economic resource and therefore the ability to learn faster than the competitor can become a distinctive competitive advantage. Consequently, there must be an organizational model that incorporates all key aspects, which gives effective responses for the company needs (Hamel \& Prahalad, 1996).

As such, we have identified and contrasted the variables that are part of the training process, which should include critical factors such as the Evaluation of Training, the Organization of training, the importance that company put on training, the identification of the basic training needs, the origin of the training, that is to say, the factors that have created the need for the establishment of a training program within the company (Pons-Peregort, 2000).

The adoption of these factors will enhance the training effectiveness. This means that a company in which the top management promotes a strong support towards a comprehensive training project, with a proper organization and evaluation scheme, 
is more likely to succeed than an organization that does not take into account these aspects, and carry out training in isolation not embedded within a comprehensive program (Pineda, 2002).

According to data obtained, it is possible to consider training as an additional strategic tool that should be used by companies to improve their performance outcomes (Molina \& Ortega, 2003; Olavarrieta \& Friedmann, 1999; Bassi et al., 2002) and its productivity (Bartel, 2000; Holzer, 1993; Barron et al., 1997; Tennant et al., 2002).

This study also contributes to the idea of building a training model that takes into account the key aspects that should comprehend a training process in any organization. This will assure that training programs would be done in a more efficient way in order to achieve business success, specifically through the continuous improvement of billing.

One of the main contributing features of this research is the exhaustive and rigorous analysis of contemporary theory that reviews all the empirical evidence and research that relate training to business results (Molina \& Ortega, 2003; Bartel, 2000; Black \& Lynch, 1996; Papalexandris \& Nikandrou, 2000).

In this empirical study it appears that some indispensable elements, such as the Evaluation of Training and the Organisation of Training, enable companies to improve their economic performance in terms of productivity, profitability and turnover.

In conclusion to this investigation, the authors assert that training can be used strategically to take advantage of technological evolution and changes presented by the market in order to achieve increased productivity from human capital; in other words, a robust training process provides a set of features that support and sustain business excellence (Aragón-Sánchez et al., 2003; Eguiguren-Huerta et al., 2008).

The results of the study further support the body of evidence that emphasizes how important training is for companies, advocating training as an additional factor that business managers can use as a strategy to tackle the various challenges that they face. 


\section{References}

ALLIGER, G.; TANNENBAUM, S.; BENNETT J r., W.; TRAVER, H.; SHOTLAND, A. (1997). A meta-analysis of the relations among training criteria. Personnel Psychology, 50: 341-358. http://dx.doi.org/10.1111/j.1744-6570.1997.tb00911.x

ARAGON-SANCHEZ, A.; BARBA-ARAGON, I.; SANZ-VALLE, R. (2003). Effects of training on business results. International Journal of Human Management, 14(6): 956-980. http://dx.doi.org/10.1080/0958519032000106164

ARAGON-SANCHEZ, A.; ESTEBAN-LLORET, N. (2010). La formación en la empresa española: ¿sólo se busca mejorar los resultados organizacionales?. Universia Business Review, 26: 34-56.

BALLOT, G.; TAYMAZ, E. (1997). The dynamics of firms in a micro-to-macro model: The role of training, learning and innovation. Journal of evolutionary economics, 7(4): 435-457. http://dx.doi.org/10.1007/s001910050052

BARCLAY, D.; HIGGINS, C.; THOMPSON, R. (1995). The Partial Least Squares (PLS) Approach to Causal Modelling: Personal Computer Adoption and Use as an Illustration. Technology Studies, Special Issue on Research Methodology, 2(2): 285-309.

BARRETT, A.; O' CONNELL, P. (2001). Does training generally work? The returns to in-company training. Industrial \& Labor Relations Review, 54(3): 647-663. http://dx.doi.org/10.2307/2695995

BARRON, J.; BERGER, M.; BLACK, D. (1997). How Well do we Measure Training? Journal of Labor Economics, 15(3): 507-528. http://dx.doi.org/10.1086/209870

BARTEL, A. (2000). Measuring the employers return on investments in training: evidence from the literature. Industrial Relations, 39(3): 502-524. http://dx.doi.org/10.1111/0019-8676.00178

BASSI, L.; LUDGWING, J.; MCMURRER, D.; VAN MURER, M. (2002). Profiting from Learning: firm-level effects of training investments and market implications. Singapore Management Review, 24(3): 61-76.

BATTU, H.; BELFIELD, C.; SLOANE, P. (2004). Human capital spillovers in the workplace: evidence for the service sector in Britain. International Journal of Manpower, 25(1): 123-138. http://dx.doi.org/10.1108/01437720410525036 
BECKER, G. (1983). El capital humano: un análisis teórico y empírico referido fundamentalmente a la educación. Madrid: Alianza Editorial.

BIRDI, K.; CLEGG, C.; PATTERSON, M.; ROBINSON, A.; STRIDE, C.; WALL, T.; WOOD, S. (2008). The impact of human resource and operational practices on company productivity: a longitudinal study. Personnel Psychology, 61: 467-501. http://dx.doi.org/10.1111/j.1744-6570.2008.00136.x

BISHOP, J. (1988). J ob performance, turnover, and wage growth. Journal of Labor Economics, 8(3): 363-386. http://dx.doi.org/10.1086/298227

BLACK, S.; LYNCH, L. (1996). Human-capital investments and productivity. American Economics Review, 86(2): 263-267.

CABRAL, L. (1997). Economía Industrial. Madrid: McGraw-Hill.

CARMINES, E.; ZELLER, R. (1979). Reliability and Validity Assessment, Sage University Paper Series on Quantitative Applications in the Social Sciences. N. 07017. Beverly Hills, CA: Sage.

CHIN, W. (1998b). The Partial Least Squares Approach to Structural Equation Modeling, en G.A. Marcoulides [ed.]: Modern Methods for Business Research. Mahwah, NJ: Lawrence Erlbaum Associates, Publisher: 295-336.

CHIN, W. (2004). PLS-Graph, Versión 3.00, University of Houston, Texas, USA.

CHU, Y. (2005). Training determinants and productivity impact of training in China: A case of Shanghai. Economics of Education Review, 24: 275-295. http://dx.doi.org/10.1016/j.econedurev.2004.05.005

COLLINS, C.; CLARK, K. (2003). Strategic human resource practices, top management team social networks, and firm performance: The role of human resource practices in creating organizational competitive advantage. Academy of Management J ournal, 46(6): 740-751. http://dx.doi.org/10.2307/30040665

COOKE, F. (2001). Human Resource Strategy to improve organizational performance: a route for firms in Britain?. International Journal of Management Reviews, 3(4): 321-339. http://dx.doi.org/10.1111/1468-2370.00071

DAVENPORT, T.; DELONG, D.; BREES, M. (1998). Successful knowledge management projects. Sloan Management Review, 39(2): 43-57. 
DENISON, E. (1979). Explanations of Declining Productivity Growth. Department of Commerce, Survey of Current Business, Part II.

DICKSON, W.; ROETHLISBERGER, F. (1986). Administración y el trabajador. The Academy of Management Review, 11(2): 459-464.

DIEZ MEDRANO, J. (1992). Métodos de análisis causal. Cuadernos Metodológicos, 3. Madrid: CIS.

DRUCKER, P. (1993). La sociedad poscapitalista. Barcelona: Apóstrofe.

DRUCKER, P. (1999). Management Challenges for the 21st Centur, (Desafíos de management para el siglo XXI), Harper Collins.

EGUIGUREN-HUERTA, M. (2000). Aspectos metodológicos de la formación en la empresa: una metodología para el control de gestión de la función de formación en la empresa en Cataluña. Tesis doctoral, Barcelona.

EGUIGUREN-HUERTA, M. (2002). Costes y beneficios de la formación en las organizaciones. Gestión de la formación en las organizaciones. Barcelona: Ariel.

EGUIGUREN-HUERTA， M.; LLINAS-AUDET， X.; PONS-PEREGORT， O. (2006). InCompany training in Catalonia: organizational structure, funding, evaluation and economic impact. International Journal of Training and Development, 10(2): 140163. http://dx.doi.org/10.1111/j.1468-2419.2005.00249.x

EGUIGUREN-HUERTA， M.; LLINAS-AUDET， X.; PARELLADA-SABATA， M. (2008). International briefing 20: training and development in Andorra. International Journal of Training and Development, 12(3): 206-224. http://dx.doi.org/10.1111/j.1468-2419.2008.00305.x

ESCARDIBUL, J.; LLINÁS-AUDET, X. (2010). International briefing 22: training and development in Spain. International Journal of Training and Development, 14(1): 65-76. http://dx.doi.org/10.1111/j.1468-2419.2009.00341.x

FOMENTO DE LA PRODUCCIÓN 30.000. 2007 y 2008. Editado por Fomento de la Producción S.L.

FORNELL, C.; LARCKER, D. (1981). Evaluating Structural Equation Models with Unobservable Variables and Measurement Error. Journal of Marketing Research, 18: 39-50. http://dx.doi.org/10.2307/3151312 
GEISSER, S. (1975). The Predictive Sample Reuse Method with Applications. Journal of the American Statistical Association: 70: 320-328. http://dx. doi.org/10.2307/2285815

HAIR, J.; ANDERSON, R.; TATHAM, R.; BLACK, W. (2000). Análisis Multivariante. 5a Edición (en español). Prentice Hall.

HAMEL, G.; PRAHALAD, C. (1996). Compitiendo por el futuro. España: Ariel.

HANDY, C. (1997). Preparando el futuro. Barcelona: Gestión 2000.

HOLZER, H.; BLOCK, R.; CHEATHAM, M.; KNOTT, J. (1993). Are training subsies for firms effective? The Michigan experience. Industrial and Labor Relations Review, 46(4): 625-636. http://dx.doi.org/10.2307/2524308

HOPE, G.; HOPE, T. (1998). Competir en la tercera ola: Los diez temas claves de la dirección en la era de la información. Madrid: Gestión 2000.

HUSELID, M. (1995). The impact of human resource management practices on turnover, productivity and corporate financial performance. Academy of Management J ournal, 38(3): 635-672. http://dx.doi.org/10.2307/256741

ICHINIOWSKI, C.; SHAW, K.; PENNUSHI, G. (1997). The effects of human resource management practices on productivity: a study of steel finishing lines. The American Economic Review, 87(3): 291-313.

JOHANNESSEN, J.; OLSEN, B. (2003). Knowledge management and sustainable competitive advantages: The Impact of dynamic contextual training. International Journal of Information Management, 23(4): 277-289. http://dx.doi.org/10.1016/S0268-4012(03)00050-1

KIRKPATRICK, D. (2003). Evaluación de acciones formativas: los cuatro niveles. Barcelona: Epise.

KRAIGER, K. (2003). Perspectives on training and development. Industrial and organizational psychology, 171-192.

KRUEGER, A.; ROUSE, C. (1998). The impact of Workplace Education on Earnings Turnover, and Job Performance. Journal of Labor Economics, 16(1): 61-94. http://dx.doi.org/10.1086/209882

LANDETA, J.; BARRUTIA, J.; HOYOS, J. (2009). Management turnover expectations: a variable to explain company readiness to engage in continuous 
management training. The International J ournal of Human Resource Management, 20: 164-185. http://dx.doi.org/10.1080/09585190802528557

LUPTON, R.; WEISS, J.; PETERSON, R. (1999). Sales Training Evaluation Model (STEM): A conceptual framework. Industrial Marketing Management, 28: 73-86. http://dx.doi.org/10.1016/S0019-8501(98)00024-8

LUQUE MARTÍNEZ, T. (2000). Técnicas de análisis de datos en investigación de mercados. Madrid: Pirámide.

LYNCH, L. (1998). Analyzing training and productivity. Monthly Labor Review, 121(7): 53-54.

MI NCER, J. (1958). Investment in Human Capital and Personal Income Distribution. The J ournal of Political Economy, 66: 281. http://dx.doi.org/10.1086/258055

MOLINA, J.; ORTEGA, R. (2003). Effects of employee on the performance of NorthAmerican firms. Applied Economics Letters, 10: 549-552. http://dx. doi.org/10.1080/1350485032000100297

MORROW, C.; JARRETT, Q.; RUPINSKI, M. (1997). An investigation of the effect and economic utility of corporate-wide training. Personnel Psycology, 50(1): 91119. http://dx.doi.org/10.1111/j.1744-6570.1997.tb00902.x

MYERS, M.; GRIFFITH, D.; DAUGHERTY, P.; LUSCH, R. (2004). Maximizing The Human Capital Ecuation in Logistics: Education, Experience and Skills. Journal of Business Logistics, 25(1): 211-232. http://dx.doi.org/10.1002/j.2158-1592.2004.tb00175.x

NAM-HONG, Y.; SOUNG-HIE, K.; HEE-WOONG, K.; KEE-YOUNG, K. (2004). Knowledge based decision making on higher level strategic concerns: system dynamics approach. Expert Systems with Applications, 27: 143-158. http://dx.doi.org/10.1016/j.eswa.2003.12.019

OLAVARRIETA, S.; FRIEDMANN, R. (1999). Market - oriented culture, knowledge related resources, reputational assets and superior performance: a conceptual framework. Journal of Strategic Marketing, 7(4): 215-228. http://dx.doi.org/10.1080/096525499346332

OTTERSTEN KAZAMAKI, E.; LINDH MELLANDER, T. (1999). Evaluating firm training, effects on performance and labour demand. Applied Economics Letters, 6: 431437. http://dx.doi.org/10.1080/135048599352943 
PAPALEXANDRIS, N.; NIKANDROU, I. (2000). Benchmarking employee skills: results from best practice firms in Greece. Journal of European Industrial Training, 24(7): 391-402. http://dx.doi.org/10.1108/03090590010377763

PARDO, A.; RUIZ, M. (2002). SPSS 11. Guía para el análisis de datos. Madrid: McGraw-Hill.

PEÑA, D. (2002). Análisis de datos multivariantes. Madrid: McGraw-Hill.

PINEDA, P. (2002). Evaluación de la formación en las organizaciones. Gestión de la formación en las organizaciones. Barcelona: Ariel.

PONS-PEREGORT, O. (2000). La Formació a les Organitzacions: una perspectiva des del disseny organizatiu de Mintzberg, Tesis doctoral.

PONS-PEREGORT, O. (2000). La Función de formación y la gestión económica de la formación en la empresa: estudio en la gran empresa catalana. Congreso AEDIPE. Construyendo un futuro más humano. La persona en la sociedad y en la empresa.

REYES, C. (2005). Analysis of the relation between knowledge engineering and knowledge management based on the Nonake and Takeuchi models. Intangible Capital 3: 1-15.

SABI, (2006-2007). Sistema de análisis de Balances Ibéricos.

SALAZAR, J. (2004). Algunas reflexiones sobre la gestión del conocimiento en las empresas. Intangible Capital, 2: 1-6.

SCHONEWILLE, M. (2001). Does training generally work? Explaining labour productivity effects from schooling and training. International Journal of Manpower, 22: 158-172. http://dx.doi.org/10.1108/01437720110386467

SCHULTZ, T. (1961). Investment in human capital. American Economic Review, Papers and Proceedings, 51: 1-17.

SCHUMPETER, J. (1982). Historia del Análisis Económico. Barcelona: Ariel.

STONE, M. (1974). Cross-validatory choice and assessment of statistical predictions. Journal of the Royal Statistical Society, 36(2): 111-147.

TAN, H.; BATRA, G. (1995). Enterprise Training in Developing Countries. PSD Occasional Paper, 9, Washington, D.C. Banco Mundial. 
TENNANT, C.; BOONKRONG, M.; ROBERTS, P. (2002). The design of a training programme measurement model. Journal of European Industrial Training, 26(5): 230-240. http://dx. doi.org/10.1108/03090590210424902

WERTS, C.; LINN, R; JÖRESKOG, K. (1974). Interclass Reliability Estimates: Testing Structural Assumptions. Educational and Psychological Measurement, 34: 25-33. http://dx.doi.org/10.1177/001316447403400104 Intangible Capital, 2011 (www.intangiblecapital.org)

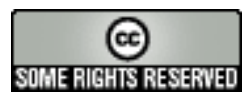

Article's contents are provided on a Attribution-Non Commercial 3.0 Creative commons license. Readers are allowed to copy, distribute and communicate article's contents, provided the author's and Intangible Capital journal's names are included. It must not be used for commercial purposes. To see the complete licence contents, please visit http://creativecommons.org/licenses/by-nc/3.0/es/ 